\title{
Analytical Methodology for the Determination of Trace Metals in Biodiesel
}

\author{
Fabiana A. Lobo' ${ }^{1}$, Danielle Goveia², \\ Leonardo F. Fraceto ${ }^{2}$ and André H. Rosa ${ }^{2}$ \\ 1 UFOP - Universidade Federal de Ouro Preto \\ 2UNESP - Universidade Estadual Paulista \\ Brazil
}

\section{Introduction}

The demand for energy resources by various systems such as production and transportation, as well as for physical comfort continues to grow apace, intensifying global dependence on fossil fuels and their derivatives. For this reason, numerous private and public programs in several countries have established feasible alternatives for the substitution of petroleum derivatives (Sahin, 2011; Saint'Pierre et al., 2003). These alternatives are aimed at reducing dependence on imported and non-renewable energy, mitigating some of the environmental impacts caused by petroleum derivatives, and developing alternative technologies in the area of energy (Oliveira et al., 2002).

Biodiesel has emerged as a promising alternative to petroleum, firstly because it promotes a qualitative and quantitative reduction of the emission of various air pollutants (Agarwai, 2005; López et al., 2005; Ilkilic \& Behcet, 2010; Silva, 2010;) and secondly, as a strategic source of renewable energy to substitute diesel oil and other petroleum derivatives (Chaves et al., 2008; Jesus et al., 2008).

Biodiesel, also known as vegetable diesel, is a fuel obtained from renewable sources, such as vegetable oils and animal fats, by means of chemical processes such as transesterification, esterification and thermal cracking (Chaves et al., 2010, Oliveira et al., 2009, Jesus et al., 2010; Arzamendi et al., 2008; Canakci et al., 1999; Meher et al., 2006).

In chemical terms, biodiesel is defined as a mono-alkyl ester of long-chain fatty acids with physicochemical characteristics similar to those of mineral diesel. Because it is perfectly miscible and physicochemically similar to mineral diesel oil, biodiesel can be used pure or mixed in any proportions with other solvents in diesel cycle engines without the need for substantial or expensive adaptations (Ma \& Hanna, 1999; Woods \& Fryer, 2007). The literature highlights several important characteristics of biodiesel: (a) its market price is still relatively high when compared with that of conventional diesel fuel; (b) its content of sulfur and aromatic compounds is lower; (c) its average oxygen content is approximately $11 \%$; (d) its viscosity and flashpoint are higher than those of conventional diesel; (e) it has a specific market niche directly associated with agricultural activities; and lastly, (f) in the case of biodiesel from used frying oil, it has strong environmental appeal (Nigam et al., 2011). The qualitative and quantitative reduction in the emissions of various air pollutants such as sulfur, particulate material, and particularly carbon, point to biodiesel as a promising 
alternative to reduce the deleterious effects of petroleum and its derivatives. However, some studies are contradictory about the concentrations of $\mathrm{NO}_{x}$ emissions, with some of them reporting a reduction in emissions, while others report marginally higher emissions than those of mineral diesel (Coronado, 2010; Costa-Neto et al., 2000; Ferrari et al., 2005; López et al., 2005; Ramadhas et al., 2004).

However, it is nigh impossible for any chemical reaction to be complete, including transesterification, and therefore the products of a reaction (alky esters) are usually contaminated with other compounds. Among metals, the ones most strongly controlled are $\mathrm{Na}$ and $\mathrm{K}$ because their hydroxides are used as catalysts. These elements, which may be present as solid abrasives or as soluble soaps, can clog various mechanical parts of a vehicle (Pohl, 2010; Chaves et al., 2008; Jesus et al., 2008). In addition, other inorganic contaminants (such as $\mathrm{Cu}, \mathrm{Pb}, \mathrm{Cd}, \mathrm{Zn}, \mathrm{Ni}$, etc.) may be present in biodiesel samples due to the plant's (raw material) absorption of metals from soil, and/or be incorporated during the production and storage process (Lobo et al., 2009; Lobo et al., 2011; Tagliabue et al., 2006).

The quantitative monitoring of metallic elements in fuel samples is of supreme importance in economic terms, not only for the fuel industry but also in various other sectors of industry and services. One of the most important applications is the determination of the total concentration or the monitoring of variations in concentration over time of certain metallic and semi-metallic elements. This type of analysis is crucial for maintaining quality control (Chaves et al., 2010; Jesus et al., 2010; Garcia et al., 1999). One of the most relevant aspects to consider is the phenomenon of corrosion in the combustion chamber of automotive engines, which is caused by high temperatures and by the fuels themselves (Amorim et al., 2007; Jesus et al., 2008; Haseeb et al., 2010; Saint ${ }^{\prime}$ Pierre et al., 2006). The deactivation of catalysts through poisoning, incrustation or solid-state transformations, which lead to reduced selectivity and loss of catalytic activity, may also result in economic losses and environmental impacts (Figueiredo \& Ribeiro, 1987; Meeravali \& Kumar, 2001; Saint’Pierre et al., 2004).

The quality of fuels supplied to the consumer, from their production to their distribution points, can be managed by means of the efficient analytical control of incidental or accidental inorganic additives (Oliveira et al., 2002).

The metal content in fuels, which is usually low, requires the use of adequate sample preparation procedures and sensitive analytical techniques (Lobo et al., 2011). Atomic absorption spectrometry (AAS) can be employed for the quantitative determination of many elements (metals and semi-metals) in a variety of foods and in biological, environmental, geological and other types of samples. The AAA technique is widely applied for the determination of different elements (about 70) due not only to its robustness but also its sensitivity to detect trace elements in the order of $\mu \mathrm{g} \mathrm{L}^{-1}$ or even ng $\mathrm{L}^{-1}$ with high accuracy and precision. The principle of the technique is based on the absorption of electromagnetic radiation from a radiation source by gaseous atoms in the fundamental state. The process of formation of gaseous atoms in the fundamental state, called atomization, can be obtained via flame, electrothermal heating, or by a specific chemical reaction such as $\mathrm{Hg}$ cold-vapor generation.

Graphite furnace atomic absorption spectrometry (GFAAS) with electrothermal atomization is widely used in routine analyses due to several factors. It requires small volumes of sample, the atomizer acts as a chemical reactor, excellent limits of detection are attained after separation of the analyte and matrix in the reactor, it requires no previous decomposition of the sample (direct analysis), it is multielemental, fast, relatively inexpensive, simple spectrum, and provides chemical and thermal pretreatment of the sample, among other advantages (Welz et al., 1992; Jackson, 1999). 
The optimization of experimental conditions in GFAAS (chemical modifiers, sample preparation, pyrolysis temperature and atomization) normally requires numerous timeconsuming and expensive experiments. However, using factorial planning enables one to extract the maximum possible amount of useful information from a given system with a minimum number of experiments. When univariate optimization is employed, it is often impossible to detect interactions among the variables under study. In addition to this problem, the number of experiments performed is usually higher when compared with those obtained through factorial design (Pereira-Filho et al., 2002; Amorim et al., 2006).

The objective of this work was to use $2^{4}$ factorial design for the optimization of experiments for the determination of metals $(\mathrm{Cu}, \mathrm{Cd}, \mathrm{Zn}, \mathrm{Ni}$ and $\mathrm{Pb})$ by GFAAS in biodiesel samples, using different sample preparation procedures and different chemical modifiers. The chemical modifiers used were a mixture of $\mathrm{Pd}+\mathrm{Mg}$ and the $\mathrm{W}$ permanent modifier, and the samples were prepared by microemulsion and focused microwave digestion. The advantages of applying factorial design to carry out the experiments and to determine the optimal conditions of pyrolysis and atomization temperatures are discussed.

\section{Experimental procedures}

\subsection{Instruments and accessories}

The instruments used in this study were a Zeeman electrothermal atomic absorption spectrometer (Varian, model Spectra AA240Z) equipped with an autosampler (Varian, model PSD 120) coupled to a Dell PC. The spectrometer's graphite tubes were designed with an integrated platform; Varian hollow cathode lamps $(\lambda=283.3 \mathrm{~nm}$, bandwidth $0.5 \mathrm{~nm}$ for $\mathrm{Pb} ; \lambda=327.4 \mathrm{~nm}$, bandwidth $0.5 \mathrm{~nm}$ for $\mathrm{Cu} ; \lambda=232.0 \mathrm{~nm}$, bandwidth $0.2 \mathrm{~nm}$ for $\mathrm{Ni} \lambda=228.8$ $\mathrm{nm}$ and bandwidth $0.5 \mathrm{~nm}$ for $\mathrm{Cd}$ ). The experimental setup included a Milli-Q Plus water deionizer system (Millipore ${ }^{\circledR}$ ); automatic micropipettes of different volumes (fixed and variable); a Sartorius 2432 analytical balance with maximum capacity of $200 \mathrm{~g}$; disposable polyethylene tubes (Corning); focused microwaves - Rapid Digestion system - SPEX. The purge gas was argon 99.9\% (White Martins, Brazil). All the measurements were based on integrated absorbance.

\subsection{Reagents, solutions and samples}

All the solutions were prepared with high purity deionized water $(18.2 \mathrm{M} \Omega . \mathrm{cm})$ purified in a deionizer system (Milli-Q Plus, Millipore ${ }^{\circledR}$ ). Nitric acid (Synth-65\% v/v) was used after sub-boiling of the reference analytical solutions and samples. Fresh analytical solutions of the analytes were prepared each day using $1000 \mathrm{mg} \mathrm{L}^{-1}$ of stock solutions (Normex ${ }^{\circledR}$, Carlo Erba) in 1.0\% (v/v) distilled $\mathrm{HNO}_{3}$, Triton X-100 (Tedia), Hydrogen Peroxide (Synth - PA, 29-30\% (v/v)), and Vanadium Pentoxide (Riedel-99.5\% m/m). The samples biodiesel were obtained from biodiesel research laboratories in Curitiba (state of Paraná) and Cuiabá (state of Mato Grosso) and from a commercial gas station in Sorocaba (state of São Paulo). According to the biodiesel suppliers, all the samples were obtained by transesterification with ethanol, using $\mathrm{NaOH}$ as catalyst. Unfortunately, no additional information was supplied for sample B10 (10\% v/v of biodiesel in diesel), which was obtained from the gas station in Sorocaba. Table 1 lists the characteristics of the samples and their respective designations. 


\begin{tabular}{|c|c|}
\hline Samples & Origin \\
\hline $\mathbf{A}_{\mathbf{1}}$ & Soybean \\
\hline $\mathbf{A}_{\mathbf{2}}$ & Soybean \\
\hline $\mathbf{A}_{3}$ & $\begin{array}{c}\text { Pure animal fat } \\
\text { (bovine grease) }\end{array}$ \\
\hline $\mathbf{A}_{\mathbf{4}}$ & $\begin{array}{c}\text { Unwashed animal fat } \\
\text { (grease mixtures) }\end{array}$ \\
\hline $\mathbf{A}_{5}$ & Washed animal fat \\
\hline $\mathbf{A}_{6}$ & Sunflower \\
\hline $\mathbf{A}_{7}$ & Cotton \\
\hline $\mathbf{A}_{8}$ & $10 \%$ biodiesel in diesel (B10) \\
\hline
\end{tabular}

Table 1. Analyzed biodiesel samples and their origins

\subsection{Preparation of the chemical modifier}

A solution of $1000 \mathrm{mg} \mathrm{L}^{-1}$ of the $\mathrm{Pd}\left(\mathrm{NO}_{3}\right)_{2}$ chemical modifier was prepared using a $10000 \mathrm{mg}$ $\mathrm{L}^{-1}$ stock solution of $\mathrm{Pd}\left(\mathrm{NO}_{3}\right)_{2}$ in $15 \% \mathrm{HNO}_{3}$ (Perkin-Elmer, Part $\mathrm{N}^{\circ}$ BO190635). A solution of $1000 \mathrm{mg} \mathrm{L}^{-1}$ of the $\mathrm{Mg}\left(\mathrm{NO}_{3}\right)_{2}$ chemical modifier was prepared using a $10000 \mathrm{mg} \mathrm{L}^{-1}$ stock solution of $\mathrm{Mg}\left(\mathrm{NO}_{3}\right)_{2}$ (Perkin-Elmer, Part $\mathrm{N}^{\circ}$ BO190634). The $\mathrm{Pd}+\mathrm{Mg}$ mixture used as chemical modifier was prepared with $5 \mu \mathrm{L}$ of a $1000 \mathrm{mg} \mathrm{L}^{-1} \mathrm{Pd}\left(\mathrm{NO}_{3}\right)_{2}$ solution $+3 \mu \mathrm{L}$ of a $1000 \mathrm{mg} \mathrm{L}^{-1} \mathrm{Mg}\left(\mathrm{NO}_{3}\right)_{2}$ solution.

The solution of $1.0 \mathrm{~g} \mathrm{~L}^{-1}$ of $\mathrm{W}$ was prepared by dissolving $0.1794 \mathrm{~g}$ of $\mathrm{NaWO}_{4} \cdot 2 \mathrm{H}_{2} \mathrm{O}$ (Merck) in $100 \mathrm{~mL}$ of deionized water. The atomizer was coated with the $\mathrm{W}$ permanent modifier in two steps: i) tungsten deposition, ii) thermal treatment of the tungsten deposited in the tube. Table 2 describes the heating program for this coating procedure.

\begin{tabular}{|c|c|}
\hline Steps & Actions and Parameters \\
\hline \multicolumn{2}{|l|}{ Deposition of $W$} \\
\hline 1 & Introduction of $50 \mu \mathrm{L}$ of a $1.0 \mathrm{~g} \mathrm{~L}^{-1} \mathrm{~W}$ solution into the atomizer \\
\hline 2 & $\begin{array}{l}\text { Heating program (ramp, hold) for drying and pyrolysis: } 120{ }^{\circ} \mathrm{C} \\
(5,25 \mathrm{~s}) ; 150^{\circ} \mathrm{C}(10,60 \mathrm{~s}) ; 600^{\circ} \mathrm{C}(20,15 \mathrm{~s}) \text { and } 1000^{\circ} \mathrm{C}(10,15 \mathrm{~s})\end{array}$ \\
\hline 3 & Steps 1 and 2 were repeated three times \\
\hline 4 & $\begin{array}{l}\text { Step } 1 \text { was repeated, followed by the heating program (ramp, } \\
\text { hold): } 120^{\circ} \mathrm{C}(5,25 \mathrm{~s}) ; 150^{\circ} \mathrm{C}(10,60 \mathrm{~s}) ; 600^{\circ} \mathrm{C}(20,15 \mathrm{~s}), 1000^{\circ} \mathrm{C}(10, \\
15 \mathrm{~s}), 1400^{\circ} \mathrm{C}(10,5 \mathrm{~s}), 2000^{\circ} \mathrm{C}(3,2 \mathrm{~s}) \text { and } 2100^{\circ} \mathrm{C}(1,1 \mathrm{~s})\end{array}$ \\
\hline \multicolumn{2}{|l|}{ Thermal treatment of $W$} \\
\hline 5 & $\begin{array}{l}\text { The heating program was repeated four times to condition the } W \\
\text { carbide to the average temperature (ramp, hold): } 150^{\circ} \mathrm{C}(1,10 \mathrm{~s}) \text {, } \\
\qquad 600^{\circ} \mathrm{C}(10,15 \mathrm{~s}), 1100^{\circ} \mathrm{C}(10,5 \mathrm{~s}) \text {, and } 1400 \mathrm{C}(10,10 \mathrm{~s})\end{array}$ \\
\hline 6 & $\begin{array}{l}\text { The heating program was repeated four times to condition the } W \\
\text { carbide to high temperatures: } 150^{\circ} \mathrm{C}(1,10 \mathrm{~s}), 600^{\circ} \mathrm{C}(10,15 \mathrm{~s}), \\
1100^{\circ} \mathrm{C}(10,5 \mathrm{~s}), 1400^{\circ} \mathrm{C}(10,10 \mathrm{~s}), 1500^{\circ} \mathrm{C}(3,5 \mathrm{~s}), 1600^{\circ} \mathrm{C}(1,1 \mathrm{~s}), \\
1700^{\circ} \mathrm{C}(1,1 \mathrm{~s}), 1800^{\circ} \mathrm{C}(1,1 \mathrm{~s}), 1900^{\circ} \mathrm{C}(1,1 \mathrm{~s}) \text { and } 2000^{\circ} \mathrm{C}(1,1 \mathrm{~s})\end{array}$ \\
\hline
\end{tabular}

Table 2. Sequence of the coating program of the atomizer with the $\mathrm{W}$ permanent chemical modifier (Oliveira et al., 2002) 


\subsection{Preparation of samples}

The samples were prepared by two procedures:

a. Microemulsion: Prepared in $50.0 \mathrm{~mL}$ volumetric flasks by mixing $0.5 \mathrm{~g}$ of biodiesel and $5 \mathrm{~g}$ of surfactant (Triton X-100) and completing the volume with $\mathrm{HNO}_{3}$ dist. $1 \%$ (v/v) under stirring for $20 \mathrm{~min}$ (Lobo et al., 2009).

b. Wet digestion: The procedure was carried out as described by Bettinelli et al. (1996), by weighing approximately $0.5 \mathrm{~g}$ of biodiesel, $18 \mathrm{~mL}$ of concentrated $\mathrm{HNO}_{3}$ dist, and $12 \mathrm{~mL}$ of $\mathrm{H}_{2} \mathrm{O}_{2}$ and $\mathrm{V}_{2} \mathrm{O}_{5}$ catalyst. The mixture was allowed to rest for $24 \mathrm{~h}$, after which it was processed in a focused microwave system (Rapid digestion System SPEX) for 1 hour (Liu et al., 1995). The procedure resulted in efficient and complete digestion, yielding a clear transparent solution. After this step, the volume was adjusted to $50.0 \mathrm{~mL}$ volume with distilled $\mathrm{HNO}_{3} 1.0 \%(\mathrm{v} / \mathrm{v})$.

\subsection{Study of the electrothermal behavior}

To evaluate the thermal behavior of the elements, pyrolysis and atomization temperature curves were built and the transient absorption signals were also analyzed. Table 3 describes the heating program applied here.

\begin{tabular}{|c|c|c|c|}
\hline Steps & $\begin{array}{c}\text { Temperature } \\
\left({ }^{\mathbf{o}} \mathbf{C}\right)\end{array}$ & $\begin{array}{c}\text { Time (s) } \\
(\text { Ramp; hold) }\end{array}$ & $\begin{array}{c}\text { Gas Flow } \\
\left(\text { mL min }^{-1}\right)\end{array}$ \\
\hline 1 & 85 & 5.0 & $300(\mathrm{Ar})$ \\
\hline 2 & 95 & 40.0 & $300(\mathrm{Ar})$ \\
\hline 3 & 120 & 10.0 & $300(\mathrm{Ar})$ \\
\hline 4 & $*$ & $5.0,3.0$ & $300(\mathrm{Ar})$ \\
\hline 5 & $* *$ & $1.0,4.0$ & $0(\mathrm{read})$ \\
\hline 6 & 2250 & $1.0,5.0$ & $300(\mathrm{Ar})$ \\
\hline
\end{tabular}

* Pyrolysis temperature (Tp); ** Atomization temperature (Ta)

Table 3. Heating program of the graphite tube atomizer

\subsubsection{Study of the electrothermal behavior to evaluate atomization and pyrolysis temperatures based on a univariate procedure}

The optimal temperature was established, and only the pyrolysis temperature was varied. After the optimal pyrolysis temperature was defined, the atomization temperature was varied. The pyrolysis and atomization curves were obtained with $25 \mu \mathrm{g} \mathrm{L}^{-1}$ (because, in the optimization of the experiments, this concentration fell within the linear range of the calibration curve) of $\mathrm{Cu}, \mathrm{Pb}, \mathrm{Ni}$ and $\mathrm{Cd}$ in the presence of two modifiers ( $\mathrm{W}$ and $\mathrm{Pd}+\mathrm{Mg}$ ) for the two sample preparation procedures (microemulsion and wet digestion in a focused microwave system).

\subsubsection{Use of experimental design to optimize pyrolysis and atomization curves}

In the process of pyrolysis and atomization temperatures, a $2^{4}$ factorial design was used for $\mathrm{Cu}, \mathrm{Pb}, \mathrm{Ni}$ and $\mathrm{Cd}$, which involved 16 assays for each analyte, as described in Tables 4 and 5 . This factorial design involved two levels, one for the lowest $(-1)$ and the other for the highest $(+1)$ temperatures, for two variables (pyrolysis and atomization temperatures), two levels for the type of sample pretreatment procedure, digestion (-1) and microemulsion (+1), 
and two levels for the type of modifier, $\mathrm{Pd}+\mathrm{Mg}(-1)$ and $\mathrm{W}(+1)$. It should be noted that the experiments were carried out randomly to avoid systemic errors.

\begin{tabular}{|c|c|c|}
\hline Factors & \multicolumn{2}{|c|}{ Levels } \\
\hline & Low (-1) & High (+1) \\
\hline Pyrolysis temperatures, ${ }^{\circ} \mathrm{C}$ & ${ }^{*}$ & ${ }^{*}$ \\
\hline Atomization temperatures, ${ }^{\circ} \mathrm{C}$ & ${ }^{*}$ & Microemulsion \\
\hline Sample preparation & Wet digestion & $\mathrm{W}$ \\
\hline Modifiers & $\mathrm{Pd}+\mathrm{Mg}$ & \\
\hline
\end{tabular}

* The pyrolysis (Tp) and atomization (Ta) temperatures at the lowest level (-1) were $100^{\circ} \mathrm{C}$ below the values recommended by the manufacturer, while the temperatures at the highest level (1) were $100^{\circ} \mathrm{C}$ above the values recommended by the manufacturer. The values recommended by the manufacturer were: $\mathrm{Pb}-\mathrm{Tp}-600^{\circ} \mathrm{C}$; Ta- $2400{ }^{\circ} \mathrm{C}$; $\mathrm{Cu}-\mathrm{Tp}-900{ }^{\circ} \mathrm{C}$; Ta- $2300{ }^{\circ} \mathrm{C}$; Ni- Tp- $900^{\circ} \mathrm{C}$; $\mathrm{Ta}-2400^{\circ} \mathrm{C}$ and $\mathrm{Cd}-\mathrm{Tp}-300^{\circ} \mathrm{C}$; Ta- $1800^{\circ} \mathrm{C}$.

Table 4. Factors and levels used in the experimental factorial design

Pyrolysis and atomization curves were obtained for $25 \mu \mathrm{g} \mathrm{L}-1$ of $\mathrm{Cu}, \mathrm{Pb}, \mathrm{Ni}$ and $\mathrm{Cd}$ in the presence of two modifiers, $\mathrm{W}$ and $\mathrm{Pd}+\mathrm{Mg}$, for both sample preparation procedures. A new factorial procedure was developed for $\mathrm{Cd}$. A $2^{2}$ factorial design involving 4 assays was developed, as described in Table 4. This factorial design involved two levels relating to the lowest (-1) and highest (+1) temperatures for the two variables (pyrolysis and atomization temperatures). The samples were prepared by microwave digestion using the $\mathrm{Pd}+\mathrm{Mg}$ chemical modifier.

\begin{tabular}{|c|c|r|c|c|c|r|}
\hline Experiments & \multicolumn{2}{|c|}{ Sample preparation } & $\begin{array}{c}\text { Pyrolysis } \\
\text { Temperature }\end{array}$ & $\begin{array}{c}\text { Atomization } \\
\text { Temperature }\end{array}$ & \multicolumn{2}{l|}{ Modifier } \\
\hline 1 & Wet Digestion & -1 & -1 & -1 & $\mathrm{Pd}+\mathrm{Mg}$ & -1 \\
\hline 2 & Microemulsion & 1 & -1 & -1 & $\mathrm{Pd}+\mathrm{Mg}$ & -1 \\
\hline 3 & Wet Digestion & -1 & 1 & -1 & $\mathrm{Pd}+\mathrm{Mg}$ & -1 \\
\hline 4 & Microemulsion & 1 & 1 & -1 & $\mathrm{Pd}+\mathrm{Mg}$ & -1 \\
\hline 5 & Wet Digestion & -1 & -1 & 1 & $\mathrm{Pd}+\mathrm{Mg}$ & -1 \\
\hline 6 & Microemulsion & 1 & -1 & 1 & $\mathrm{Pd}+\mathrm{Mg}$ & -1 \\
\hline 7 & Wet Digestion & -1 & 1 & 1 & $\mathrm{Pd}+\mathrm{Mg}$ & -1 \\
\hline 8 & Microemulsion & 1 & 1 & 1 & $\mathrm{Pd}+\mathrm{Mg}$ & -1 \\
\hline 9 & Wet Digestion & -1 & -1 & -1 & $\mathrm{~W}$ & 1 \\
\hline 10 & Microemulsion & 1 & -1 & -1 & $\mathrm{~W}$ & 1 \\
\hline 11 & Wet Digestion & -1 & 1 & -1 & $\mathrm{~W}$ & 1 \\
\hline 12 & Microemulsion & 1 & 1 & -1 & $\mathrm{~W}$ & 1 \\
\hline 13 & Wet Digestion & -1 & -1 & 1 & $\mathrm{~W}$ & 1 \\
\hline 14 & Microemulsion & 1 & -1 & 1 & $\mathrm{~W}$ & 1 \\
\hline 15 & Wet Digestion & -1 & 1 & 1 & $\mathrm{~W}$ & 1 \\
\hline 16 & Microemulsion & 1 & 1 & 1 & $\mathrm{~W}$ & 1 \\
\hline
\end{tabular}

Table 5. First factorial design for the optimization of pyrolysis and atomization 


\subsection{Determination of metals by the calibration procedure using the analyte addition method}

Based on the results obtained with the experimental design, the methods were optimized using the two sample preparation procedures (Lobo et al., 2009, 2011).

The analyte addition method consists of adding volumes of solutions with known concentrations of analyte to the sample. This method is especially suitable when the composition of the sample is unknown or complex, as is the case of biodiesel samples. Thus, aiming to minimize interferences (since the standards and the sample had the same composition and physical properties), the analyte was quantified even when present in low concentrations, to ensure that the measures of the analytic signals would fall within a suitable interval for the technique (Harris, 2001) in the two different sample preparation procedures.

For each microemulsified sample, four standards were prepared containing different concentrations of added $\mathrm{Cd}$ and $\mathrm{Ni}$, as shown in Table 6 (the concentration interval was used based on the manufacturer's handbook).

\begin{tabular}{|c|c|c|c|c|}
\hline Flask & $\mathbf{V a}^{*}(\mathbf{m L})$ & $\begin{array}{c}{[\mathrm{Cd}]} \\
\mathbf{a d d e d} \\
\mu \mathbf{g ~ L}^{-1}\end{array}$ & $\begin{array}{c}{[\mathbf{N i}] \text { added }} \\
\mu \mathbf{g ~ L}^{-1}\end{array}$ & $\begin{array}{c}\text { Final volume } \\
(\mathbf{m L})\end{array}$ \\
\hline 1 & 1.0 & 0 & 0 & 10.0 \\
\hline 2 & 1.0 & 0.5 & 5.0 & 10.0 \\
\hline 3 & 1.0 & 1.0 & 10.0 & 10.0 \\
\hline 4 & 1.0 & 1.5 & 15.0 & 10.0 \\
\hline
\end{tabular}

*Va - volume of sample added in the form of microemulsion.

Table 6. Preparation of the monoelemental standards using the analyte addition method for the microemulsified samples

For each digested sample, four standards were prepared containing different concentrations of added $\mathrm{Cu}, \mathrm{Pb}, \mathrm{Cd}$ and $\mathrm{Ni}$, as shown in Table 7 (the concentration interval was used based on the manufacturer's handbook).

\begin{tabular}{|c|c|c|c|c|c|c|}
\hline Flask & $\begin{array}{c}\mathbf{V a}^{*} \\
(\mathbf{m L})\end{array}$ & $\begin{array}{c}{[\mathrm{Cu}]} \\
\mathbf{a d d e d} \\
\mu \mathrm{g} \mathrm{L}^{-1}\end{array}$ & $\begin{array}{c}{[\mathrm{Pb}]} \\
\mathbf{a d d e d} \\
\mu \mathrm{g} \mathrm{L}^{-1}\end{array}$ & $\begin{array}{c}{[\mathrm{Ni}]} \\
\mathbf{a d d e d} \\
\mu \mathrm{g} \mathrm{L}^{-1}\end{array}$ & $\begin{array}{c}{[\mathrm{Cd}]} \\
\mathbf{a d d e d} \\
\mu \mathrm{g} \mathrm{L}^{-1}\end{array}$ & $\begin{array}{c}\text { Final } \\
\mathbf{v o l u m e} \\
(\mathbf{m L})\end{array}$ \\
\hline 1 & 1.0 & 0 & 0 & 0 & 0 & 10.0 \\
\hline 2 & 1.0 & 5.0 & 15.0 & 5.0 & 0.5 & 10.0 \\
\hline 3 & 1.0 & 10.0 & 30.0 & 10.0 & 1.0 & 10.0 \\
\hline 4 & 1.0 & 15.0 & 45.0 & 15.0 & 1.5 & 10.0 \\
\hline
\end{tabular}

*Va - volume of focused microwave digested sample

Table 7. Preparation of the monoelemental standards using the analyte addition method for the digested samples 


\subsection{Analytical characteristics}

The analytical characteristics of the procedures developed with the limit of detection (LOD), limit of quantification (LOQ), estimated standard deviation (SD) and relative standard deviation (RSD) were calculated as described by Harris (2001).

The variances were compared by the F test (Baccan et al., 1985; Vogel, 1992) and the concurrency between the means was verified by Student's $t$-test (Harris, 2001).

\section{Results and discussion}

3.1 Evaluation of the electrothermal behavior of the analytes by the univariate method The elements $\mathrm{Pb}$ and $\mathrm{Cd}$ are relatively volatile, which makes the use of chemical modifiers indispensable. Therefore, $\mathrm{Pd}+\mathrm{Mg}$ and $\mathrm{W}$ were used as chemical modifiers to thermally stabilize the analytes, enabling the satisfactory elimination of most of the matrix, and thus reducing possible interferences.

\subsubsection{Determination of pyrolysis and atomization temperatures of the microemulsified} samples by the univariate method

Pyrolysis and atomization curves were obtained for $\mathrm{Cu}, \mathrm{Pb}, \mathrm{Ni}$ and $\mathrm{Cd}$ in the presence of two modifiers, $\mathrm{W}$ and Pd $+\mathrm{Mg}$ (Lobo et al., 2009). An analysis of the curves revealed a slight difference in sensitivity when using the $\mathrm{Pd}+\mathrm{Mg}$ or $\mathrm{W}$ modifier. Hence, analyzing solely the pyrolysis and atomization temperature curves did not allow for conclusions to be drawn about the optimal chemical modifier for the analytes in question. Table 8 lists the Tp and Ta chosen for the analytes (according to the curves).

\begin{tabular}{|c|c|c|c|c|}
\hline \multirow{2}{*}{ Elements } & \multicolumn{2}{|c|}{ Tp $\left({ }^{\circ} \mathrm{C}\right)^{*}$} & \multicolumn{2}{c|}{ Ta $\left({ }^{\circ} \mathrm{C}\right)^{*}$} \\
\cline { 2 - 5 } & $\mathbf{P d}+\mathbf{M g}$ & $\mathbf{W}$ & $\mathbf{P d}+\mathbf{M g}$ & $\mathbf{W}$ \\
\hline $\mathrm{Cu}$ & 900 & 900 & 2700 & 2500 \\
\hline $\mathrm{Pb}$ & 900 & 700 & 2300 & 1600 \\
\hline $\mathrm{Ni}$ & 900 & 1200 & 3000 & 3000 \\
\hline $\mathrm{Cd}$ & 400 & 300 & 1700 & 2000 \\
\hline
\end{tabular}

* Pyrolysis temperatures (Tp) and atomization temperatures (Ta)

Table 8. Values of pyrolysis (Tp) and atomization (Ta) temperatures of the microemulsified samples for the two modifiers used.

\subsubsection{Pyrolysis and atomization temperature curves of focused microwave digested samples using the univariate method}

Pyrolysis and atomization temperature curves were obtained for $\mathrm{Cu}, \mathrm{Pb}, \mathrm{Ni}$ and $\mathrm{Cd}$ in the presence of two modifiers, $\mathrm{W}$ and $\mathrm{Pd}+\mathrm{Mg}$ (LOBO et al., 2009). The results revealed a certain similarity with the procedure using microemulsion, i.e., there was a minor difference in sensitivity when using the $\mathrm{Pd}+\mathrm{Mg}$ or $\mathrm{W}$ modifier. Table 9 lists the $\mathrm{Tp}$ and Ta chosen for the analytes. 


\begin{tabular}{|c|c|c|c|c|}
\hline \multirow{2}{*}{ Elements } & \multicolumn{2}{|c|}{$\mathbf{T p}\left({ }^{\circ} \mathbf{C}\right)^{*}$} & \multicolumn{2}{c|}{ Ta $\left({ }^{\circ} \mathbf{C}\right)^{*}$} \\
\cline { 2 - 5 } & $\mathbf{P d}+\mathbf{M g}$ & $\mathbf{W}$ & $\mathbf{P d}+\mathbf{M g}$ & $\mathbf{W}$ \\
\hline $\mathrm{Cu}$ & 1000 & 1000 & 2600 & 2600 \\
\hline $\mathrm{Pb}$ & 900 & 800 & 2000 & 1800 \\
\hline $\mathrm{Ni}$ & 1500 & 1400 & 2600 & 2400 \\
\hline $\mathrm{Cd}$ & 550 & 550 & 2000 & 1800 \\
\hline
\end{tabular}

* Pyrolysis temperatures (Tp) and atomization temperatures (Ta)

Table 9. Values of pyrolysis (Tp) and atomization (Ta) temperatures of the digested samples for the two modifiers used

\subsection{Evaluation of the electrothermal behavior using experimental design 3.2.1 Results of the optimization of pyrolysis and atomization temperatures using experimental design}

The optimization method using factorial design evaluates the interactions between the important variables, as well as their simultaneous combination. Table 10 illustrates the results of absorbance for the elements evaluated using $2^{4}$ factorial design.

\begin{tabular}{|c|c|c|c|c|}
\hline Experiments & $\mathbf{C u}$ & $\mathbf{P b}$ & $\mathbf{N i}$ & $\mathbf{C d}$ \\
\hline 1 & 0.0974 & 0.1562 & 0.0658 & 0.3810 \\
\hline 2 & 0.0651 & 0.0483 & 0.0912 & 0.3520 \\
\hline 3 & 0.0988 & 0.1506 & 0.0651 & 0.5010 \\
\hline 4 & 0.0656 & 0.0555 & 0.0824 & 0.5390 \\
\hline 5 & 0.0991 & 0.1538 & 0.0744 & 0.3840 \\
\hline 6 & 0.0701 & 0.0452 & 0.0968 & 0.3520 \\
\hline 7 & 0.0945 & 0.1406 & 0.0621 & 0.4170 \\
\hline 8 & 0.0694 & 0.0431 & 0.0908 & 0.3130 \\
\hline 9 & 0.0971 & 0.1599 & 0.632 & 0.3120 \\
\hline 10 & 0.0636 & 0.0488 & 0.0947 & 0.3310 \\
\hline 11 & 0.1008 & 0.1597 & 0.0894 & 0.4560 \\
\hline 12 & 0.0630 & 0.0430 & 0.0626 & 0.4600 \\
\hline 13 & 0.1033 & 0.1673 & 0.0921 & 0.2720 \\
\hline 14 & 0.0759 & 0.0356 & 0.0735 & 0.3040 \\
\hline 15 & 0.1044 & 0.1455 & 0.0905 & 0.3530 \\
\hline 16 & 0.0706 & 0.0397 & 0.0769 & 0.3950 \\
\hline
\end{tabular}

Note: This factorial design has two levels, (-) for the lower level and (+) for the upper level, related to the sample preparation (Variable 1), i.e., digestion (-) and microemulsion (+), levels related to the lowest $(-)$ and highest (+) temperatures for the two variables of pyrolysis temperature (Variable 2) and atomization temperature (Variable 3), as well as levels related to the type of modifier used (Variable 4) $\mathrm{Pd}+\mathrm{Mg}(-)$ and $\mathrm{W}(+)$.

Table 10. Analyte absorbance values using factorial design 
Pareto charts, graphics showing the values of effects and graphics showing special values are the ones most commonly used to evaluate the interactions between variables and to pinpoint the significant variables. In this work, values vs. probability graphics were prepared for the four analytes. In this type of graphic, the effects are calculated as a function of absorbance values, considering the levels (+ and -) presented in thematrix of the sample. The graphics of values of the effects vs. the scale of probability are presented in Figure 1 (adapted from Lobo et al., 2009).

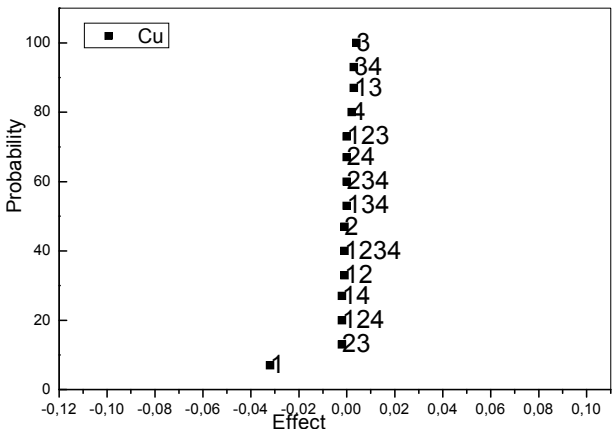

a)

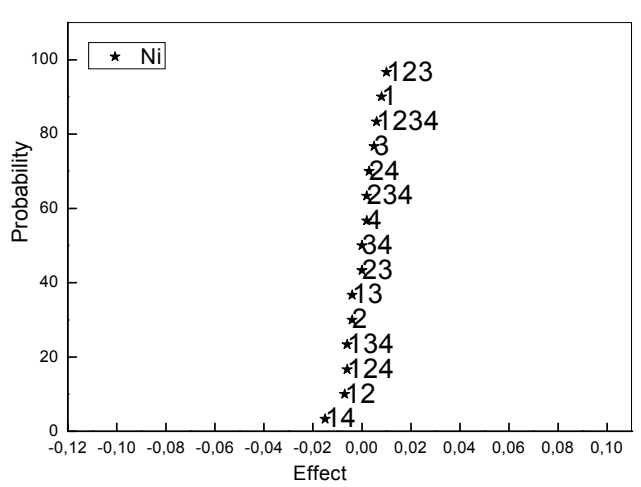

c)

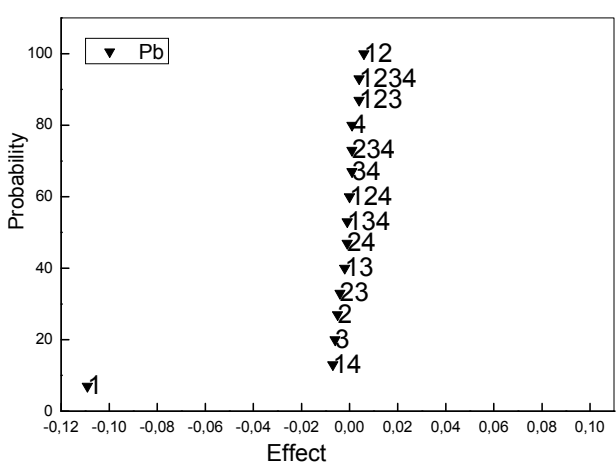

b)

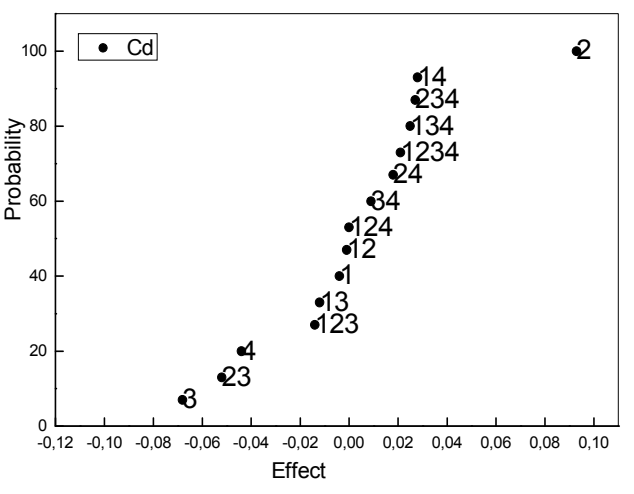

d)

Fig. 1. Graphic of the value of the effects of the variables on the GFAAS optimization of the pyrolysis and atomization temperatures of biodiesel samples: a) $\mathrm{Cu}, \mathrm{b}) \mathrm{Pb}, \mathrm{c}) \mathrm{Ni}, \mathrm{d}) \mathrm{Cd}$

On the plot of a graphic of scale of probability vs. value of the effect, the smaller points that tend to form a straight line are considered insignificant, while the larger (in value of the effect) and the further apart the points are, the more significant the effect.

In Figures $1 \mathrm{a}$ and $\mathrm{1b}$, the optimization graphic for $\mathrm{Cu}$ and $\mathrm{Pb}$ shows that variable 1 (sample preparation) in focused microwave digestion (defined as (-), Table 5) is more important for the two analytes (higher effect of absorbance), since this point was further away from the others, while the other variables were indifferent, indicating that any modifier could be used. The ideal pyrolysis and atomization temperatures were chosen according to the 
highest sensitivity, taking into account the lowest temperatures that least degrade the graphite tube. Thus, the pyrolysis and atomization temperatures chosen were $1000{ }^{\circ} \mathrm{C}$ and $2200^{\circ} \mathrm{C}$ for $\mathrm{Cu}$ and $500^{\circ} \mathrm{C}$ and $2000^{\circ} \mathrm{C}$ for $\mathrm{Pb}$, respectively.

Figure 1c shows that none of the evaluated variables were important for $\mathrm{Ni}$. The pyrolysis and atomization temperatures chosen for $\mathrm{Ni}$ were $800^{\circ} \mathrm{C}$ and $2300^{\circ} \mathrm{C}$. As can be seen in the optimization graph for $\mathrm{Cd}$ in Figure $1 \mathrm{~d}$, the variables that were most distant were variables 2 and 3, indicating that the temperature of pyrolysis must be increased and that of atomization decreased to ensure greater efficiency in the process. This finding points to the need to use another factorial design for this element. The variables medium (1) and modifier (4) were not important, indicating that any medium or modifier can be used.

3.2.1.1 Results of the evaluation of pyrolysis and atomization temperatures using a second experimental design for $\mathrm{Cd}$

Table 11 describes the optimization method using factorial design for $\mathrm{Cd}$.

\begin{tabular}{|c|c|c|c|c|c|}
\hline Experiments & $\begin{array}{c}\text { Sample } \\
\text { Preparation }\end{array}$ & $\begin{array}{c}\text { Pyrolysis } \\
\text { Temperature }\end{array}$ & $\begin{array}{c}\text { Atomization } \\
\text { Temperature }\end{array}$ & Modifier & Cd \\
\hline 1 & Digestion & - & - & $\mathrm{Pd}+\mathrm{Mg}$ & 0.7622 \\
\hline 2 & Digestion & + & - & $\mathrm{Pd}+\mathrm{Mg}$ & 0.8427 \\
\hline 3 & Digestion & - & + & $\mathrm{Pd}+\mathrm{Mg}$ & 0.7274 \\
\hline 4 & Digestion & + & + & $\mathrm{Pd}+\mathrm{Mg}$ & 0.7707 \\
\hline
\end{tabular}

Table 11. Values of absorbance for the factorial design used for $\mathrm{Cd}$

The values of the effects were too small for the design employed. Therefore, lower temperatures were chosen, $\mathrm{Tp}-500^{\circ} \mathrm{C}$ and $\mathrm{Ta}-1400^{\circ} \mathrm{C}$, thereby increasing the service life of the graphite tube.

The formation of metal carbide (or oxycarbide) deposits on the platform of the graphite tube or directly on the wall of the tube is an interesting modification strategy to prolong the service life of the graphite tube when working with aggressive solvents or matrices. In addition to acting as a coating on the tube and/or as a modifier, these carbides can promote the decomposition of the matrix through catalytic effects, acting as catalysts and destroying the concomitants of the matrix prior to atomization of the analyte, thereby minimizing or eliminating possible interferences (Freschi et al., 2005). The results obtained for all the metals using the experimental design did not differ when working with either $\mathrm{Pd}+\mathrm{Mg}$ or $\mathrm{W}$. Therefore, we decided to work with $\mathrm{W}$ since, besides the advantages mentioned earlier, the heating programs are faster (and thus the determinations are faster), there is less contamination because purification is done in situ, there are few background-related problems, and the modifier's volatile impurities can be eliminated, thus improving the limits of detection (Saint'Pierre et al., 2002).

Table 12 summarizes and compares the defined temperatures using the univariate and multivariate methods. 


\begin{tabular}{|c|c|c|c|c|c|}
\hline \multirow{3}{*}{ Elements } & \multirow{3}{*}{ Modifier } & \multicolumn{2}{|c|}{ Microwave digestion } & \multicolumn{2}{|c|}{ Microemulsion } \\
\hline & & $\begin{array}{c}\text { Conventiona } \\
\text { l Method }\end{array}$ & $\begin{array}{c}\text { Multivariate } \\
\text { Method }\end{array}$ & $\begin{array}{l}\text { Conventiona } \\
\text { l Method }\end{array}$ & $\begin{array}{c}\text { Multivariate } \\
\text { Method }\end{array}$ \\
\hline & & $\mathrm{Tp} / \mathrm{Ta}^{*}$ & $\mathrm{Tp} / \mathrm{Ta}$ & $\mathrm{Tp} / \mathrm{Ta}$ & $\mathrm{Tp} / \mathrm{Ta}$ \\
\hline \multirow[t]{2}{*}{$\mathrm{Cu}$} & $\mathrm{Pd}+\mathrm{Mg}$ & $1000 / 2600$ & \multirow{2}{*}{1000 / 2200} & $900 / 2700$ & \multirow{2}{*}{-} \\
\hline & W & $1000 / 2600$ & & $900 / 2500$ & \\
\hline \multirow[t]{2}{*}{$\mathrm{Pb}$} & $\mathrm{Pd}+\mathrm{Mg}$ & 900 / 2000 & \multirow{2}{*}{500 / 2000} & $900 / 2300$ & \multirow{2}{*}{ - } \\
\hline & W & 800 / 1800 & & $700 / 1600$ & \\
\hline \multirow[t]{2}{*}{$\mathrm{Ni}$} & $\mathrm{Pd}+\mathrm{Mg}$ & $1500 / 2600$ & \multirow{2}{*}{$800 / 2300$} & $900 / 3000$ & \multirow{2}{*}{800 / 2300} \\
\hline & W & $1400 / 2400$ & & 1200 / 3000 & \\
\hline \multirow[t]{2}{*}{$\mathrm{Cd}$} & $\mathrm{Pd}+\mathrm{Mg}$ & 550 / 2000 & \multirow{2}{*}{$500 / 1400$} & $400 / 1700$ & \multirow{2}{*}{500 / 1400} \\
\hline & W & $550 / 1800$ & & $300 / 2000$ & \\
\hline
\end{tabular}

* $\mathrm{Tp}$ - Pyrolysis temperature, ${ }^{\circ} \mathrm{C} / \mathrm{Ta}$ - Atomization temperature, ${ }^{\circ} \mathrm{C}$

Table 12. Comparison of the optimal values of pyrolysis and atomization temperatures using univariate and multivariate methods

An analysis of Table 12 indicates that the values of the temperatures using factorial design are usually conditions of milder temperatures. Despite a certain difference in sensitivity, the use of experimental design offers several advantages, such as the definition of suitable experimental parameters (sample preparation, chemical modifiers), help in the definition of pyrolysis and atomization temperatures and evaluation of the interactions between the variables under study.

This emphasizes the importance of the simultaneous optimization of all the factors involved in the system, with fewer experiments, greater speed, and particularly higher efficiency. The chosen temperatures were therefore those listed in Table 18 for the multivariate method, for each specific analyte.

\subsection{Evaluation of the influence of standards in the determination of metals}

One of the major advantages of systems that use microemulsions is precisely the fact that they use inorganic standards for the determinations (Aucélio et al., 2004). Conversely, organic standards have several disadvantages, such as high cost, instability, they are very dangerous, carcinogenic, and often require the use of special apparatuses and equipment. However, numerous studies have used emulsified standards and not aqueous standards (Chaves et al., 2008a, 2008b; Jesus et al., 2008; Saint'Pierre et al., 2004; Giacomelli et al., 2004), justifying this choice based on the fact that in most cases emulsified standards are more stable, as well as the difference in sensitivity compared to aqueous standards.

Figure 2 illustrates the results of the equations adjusted for the seven biodiesel samples evaluated by the analyte addition method, aiming at a comparison of the behavior of $\mathrm{Cd}$ in the different matrices (emulsified standards) and in aqueous standards. The range of concentrations used was based on the interval recommended by the manufacturer. 


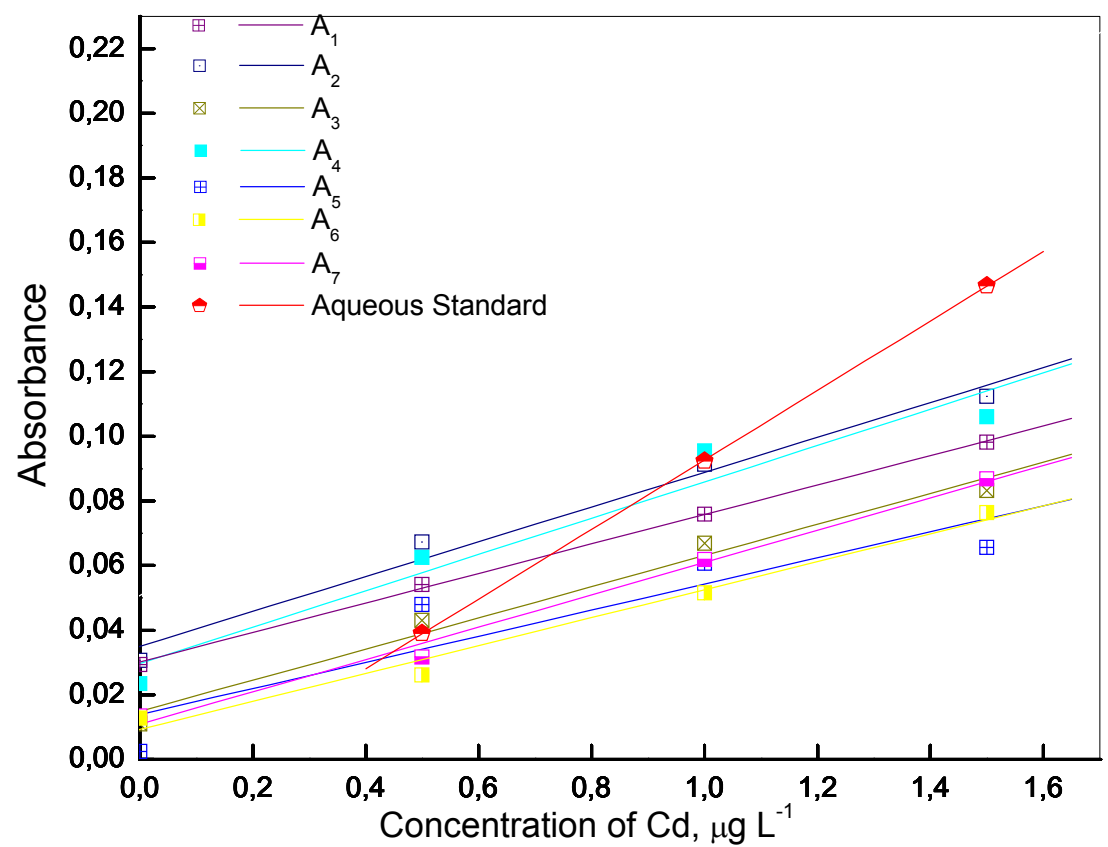

Fig. 2. Equations adjusted to the analytical curves for the determination of $\mathrm{Cd}$ in the 8 samples. $S_{1}: A=0.03017+0.0456[C d], r=0.99961 ; S_{2}: A=0.03503+0.05386[C d], r=0.9995 ; S_{3}: A=$ $0.01486+0.04822[\mathrm{Cd}], \mathrm{r}=0.98956 ; \mathrm{S}_{4}: \mathrm{A}=0.02971+0.05622[\mathrm{Cd}], \mathrm{r}=0.9737 ; \mathrm{S}_{5}: \mathrm{A}=-0.01386+$ $0.04042[\mathrm{Cd}], \mathrm{r}=0.98695 ; \mathrm{S}_{6}: \mathrm{A}=0.00931+0.04322[\mathrm{Cd}], \mathrm{r}=0.99141 ; \mathrm{S}_{7}: \mathrm{A}=0.01088+$ 0.05006[Cd], $\mathrm{r}=0.99595 ; \mathrm{r}=0.97394 ;$ Aqueous standard: $\mathrm{A}=0.01493+0.1076[\mathrm{Cd}], \mathrm{r}=0.99999$.

As can be seen in Figure 2, there is a significant difference between the analyzed standards. The sensitivities of the analytical curves for pure biodiesel (samples $S_{1}$ to $S_{7}$ ) are consistently lower for the aqueous standard, confirming the reports of some studies in the literature that the sensitivities of emulsified standards differ from those of aqueous standards (Cassella et al., 2004; Reyes \& Campos, 2005; Saint’Pierre et al., 2002, 2003, 2006).

It was also found that the analytical curves of the biodiesel samples did not exhibit the same sensitivity, although they were similar. This distinct behavior of the samples' analytical curves can be explained by the differences in the composition of the analyzed samples, i.e., fat content, viscosity, source, origins, production processes, etc. Thus, each sample was determined using emulsified standards.

A curve was also built for sample B10, but because most of this sample consisted of diesel $(90 \%)$, it did not show good stabilization and the resulting values were inadequate for the determination of the analytes in this sample.

\subsection{Determination of metals by the calibration procedure using the analyte addition method}

\subsubsection{Determination of $\mathrm{Ni}$ and $\mathrm{Cd}$ in microemulsified samples of biodiesel}

The best way to calculate the limits of detection (LOD) and of quantification (LOQ) when using the analyte addition method is to pass standards of low concentrations until the 
lowest signals corresponding to the lowest detectable concentration are found. The estimated standard deviation (SD) is then calculated for 10 measures of the standard with the lowest concentration, after which the values of LOD and LOQ can be calculated according to the literature, i.e., $\mathrm{LOD}=(3 \mathrm{sd}) / \mathrm{K}$ and $\mathrm{LOQ}=(10 \mathrm{sd}) / \mathrm{K}$, where $\mathrm{k}$ is the slope of the straight line (Baccan et al., 1985; Vogel, 1992). However, due to the experimental difficulties resulting from the need to conclude this work, the LOD and LOQ were calculated using the traditional procedure, considering the blank of the samples instead of the standard with the lowest concentration. Table 13 lists the values of the limits of detection and quantification, as well as the concentrations of $\mathrm{Ni}$ and $\mathrm{Cd}$ obtained in the samples.

\begin{tabular}{|c|c|c|c|c|c|c|}
\hline \multirow{2}{*}{ Sample } & \multicolumn{2}{|c|}{$\begin{array}{l}\text { LOD }_{\text {found, }} \\
\quad \mu \mathrm{g} \mathrm{L}^{-1}\end{array}$} & \multicolumn{2}{|c|}{$\begin{array}{l}\mathrm{LOQ}_{\text {found, }} \\
\quad \mu \mathrm{g} \mathrm{L}^{-1}\end{array}$} & \multicolumn{2}{|c|}{$\begin{array}{c}{[\mathrm{C}]^{*} \text { obtained in the sample, }} \\
\mu \mathrm{g} \mathrm{g} \mathrm{g}^{-1} \pm \mathrm{sd}\end{array}$} \\
\hline & $N i$ & $C d$ & $N i$ & $C d$ & $N i$ & $C d$ \\
\hline$S_{1}$ & 0.78 & 0.10 & 2.67 & 0.36 & $\leq \mathrm{LOD}$ & 0.66 \\
\hline $\mathrm{S}_{2}$ & 0.81 & 0.10 & 2.71 & 0.31 & $\leq \mathrm{LOD}$ & 0.61 \\
\hline $\mathrm{S}_{3}$ & 0.85 & 0.10 & 2.85 & 0.34 & $\leq \mathrm{LOD}$ & 0.19 \\
\hline $\mathrm{S}_{4}$ & 0.44 & 0.07 & 1.47 & 0.23 & $\leq \mathrm{LOD}$ & 0.33 \\
\hline $\mathrm{S}_{5}$ & 0.41 & 0.12 & 1.37 & 0.40 & $\leq \mathrm{LOD}$ & $\leq \mathrm{LOD}$ \\
\hline $\mathrm{S}_{6}$ & 0.29 & 0.12 & 0.97 & 0.39 & $\leq \mathrm{LOD}$ & 0.21 \\
\hline $\mathrm{S}_{7}$ & 0.46 & 0.10 & 1.53 & 0.33 & $\leq \mathrm{LOD}$ & 0.21 \\
\hline
\end{tabular}

*Concentration of the analyte

Table 13. Concentrations of $\mathrm{Ni}$ and Cd, and LOD and LOQ found for the samples

Table 13 indicates that low limits of detection (LOD $\leq 0.85 \mu \mathrm{g} \mathrm{L}-1$ ) were obtained for $\mathrm{Ni}$, but $\mathrm{Ni}$ was undetectable in the samples using this method. Many explanations can be considered, since $\mathrm{Ni}$ is usually present in fuels as volatile $\mathrm{Ni}$ and low molecular mass $\mathrm{Ni}$ complex (Vale et al., 2004) and may have been lost during the analyses.

Low limits of detection (LOD $\leq 0.12 \mu \mathrm{g} \mathrm{L}^{-1}$ ) were obtained for $\mathrm{Cd}$ by the analyte addition method. The concentrations of cadmium found in the samples were low, but were above the respective limits of detection obtained statistically.

As can be seen in Table 13, sample $S_{5}$ (washed animal fat) presented no concentration of $C d$, probably because it was eliminated during the washing step of the biodiesel production process, rendering it undetectable in the sample analyzed by the proposed method.

$\mathrm{Cd}$ values obtained in samples of animal fat are always lower than those found in samples of vegetable biodiesel. This is probably due to the fact that vegetables can absorb metals from the soil, which is not the case in samples of animal origin. Moreover, cadystins may also be present, which are synthesized by the majority of higher plants and are also present in algae and fungi. The presence of $\mathrm{Cd}$ in biodiesel can be attributed to the high mobility of this element in soil (Costa-Neto et al., 2007; Oliveira, et al., 2001). Another important factor that deserves mention is that $\mathrm{Cd}$ has been used in the form of $\mathrm{CdCl}_{2}$ as a fungicide, and can be considered a source of soil contamination (Hernández-Caraballo et al., 2004; Campos et al., 2005). 


\subsubsection{Analyte addition and recovery test}

Due to the lack of certifies reference material for biodiesel, the analyte addition and recovery test was used to evaluate the accuracy of the method. Table 14 lists the results obtained for each sample.

\begin{tabular}{|c|c|c|}
\hline \multirow{2}{*}{ Sample } & \multicolumn{2}{|c|}{ Recovery rates, $\%$} \\
\cline { 2 - 3 } & $\mathbf{N i} \pm$ RSD $^{*}$ & $\mathbf{C d} \pm \mathbf{R S D}$ \\
\hline$S_{1}$ & $108 \pm 1.5$ & $100 \pm 4.3$ \\
\hline$S_{2}$ & $105 \pm 0.7$ & $104 \pm 3.3$ \\
\hline$S_{3}$ & $103 \pm 2.9$ & $108 \pm 0.6$ \\
\hline$S_{4}$ & $102 \pm 1.8$ & $99 \pm 3.7$ \\
\hline$S_{5}$ & $101 \pm 3.0$ & $116 \pm 3.7$ \\
\hline$S_{6}$ & $93 \pm 8.2$ & $98 \pm 4.7$ \\
\hline$S_{7}$ & $97 \pm 2.7$ & $102 \pm 4.6$ \\
\hline$S_{8}$ & $93 \pm 0.8$ & $95 \pm 1.8$ \\
\hline
\end{tabular}

*RSD - relative standard deviation

Table 14. Recovery rates $(n=3)$ and relative standard deviations of the biodiesel samples, using $\mathrm{W}$ as modifier, prepared with $10 \mu \mathrm{g} \mathrm{L}-1$ of Ni and $1.0 \mu \mathrm{g} \mathrm{L} \mathrm{L}^{-1}$ of $\mathrm{Cd}$

The accuracy of an analysis depends on the matrix, on sample processing, and on analyte concentration. Data in the AOAC handbook ("Peer Verified Methods Program") indicate that, for concentrations of $\leq 10 \mu \mathrm{g} \mathrm{L}^{-1}$, recovery rates of $40 \%$ to $120 \%$ are acceptable (National Health Surveillance Agency - ANVISA, 2009).

Table 14 shows that the recovery rates varied from $93 \%$ to $108 \%$ for $\mathrm{Ni}$ and from $95 \%$ to $116 \%$ for $\mathrm{Cd}$, indicating that the method used here is suitable for the determination of $\mathrm{Ni}$ and $\mathrm{Cd}$ in matrices of biodiesel from different sources and origins. Satisfactory RSD values were obtained, i.e., $\leq 8.2 \%$ (sample $S_{7}$ ) and $\leq 4.7 \%$ (sample $S_{8}$ ) for $10.0 \mu \mathrm{g} \mathrm{\textrm {L } ^ { - 1 }}$ of Ni and $1.0 \mu \mathrm{g}$ $\mathrm{L}^{-1}$ of $\mathrm{Cd}$, respectively.

\subsubsection{Determination of $\mathrm{Cu}, \mathrm{Pb}, \mathrm{Ni}$ and $\mathrm{Cd}$ in digested biodiesel samples}

Due to the difference in sensitivity obtained by the emulsified and aqueous standards, the analytes were determined here using standards in the presence of digested samples by the analyte addition method.

After a certain period of storage, the sample of unwashed animal fat (sample $\mathrm{S}_{4}$ ) presented nodules (like fatty stones), so this sample could not be homogenized and was therefore not subjected to the digestion procedure.

The sample of cotton origin $\left(\mathrm{S}_{7}\right)$ could not be digested because it presented fatty residues at the end of the digestion procedure. Although all the samples were similar, samples of cotton origin should show higher organic loads than other samples, and the amount of acid used was insufficient for the complete digestion of this sample.

Table 15 lists the concentrations of $\mathrm{Cu}, \mathrm{Pb}, \mathrm{Ni}$ and $\mathrm{Cd}$, and the limits of detection and quantification found for the digested samples. 


\begin{tabular}{|c|c|c|c|c|c|c|c|c|c|c|c|c|}
\hline \multirow{2}{*}{ Sample } & \multicolumn{4}{|c|}{ LOD, $\mu \mathrm{g} \mathrm{L-1}$} & \multicolumn{4}{|c|}{ LOQ,$\mu \mathrm{g} \mathrm{L-1}$} & \multicolumn{4}{|c|}{$[C]^{*}, \mu \mathrm{g} g-1$} \\
\hline & $C u$ & $\mathrm{~Pb}$ & $\mathrm{Ni}$ & $C d$ & $\mathrm{Cu}$ & $\mathrm{Pb}$ & $N i$ & $C d$ & $C u$ & $\mathrm{~Pb}$ & $\mathrm{Ni}$ & $C d$ \\
\hline $\mathrm{S}_{1}$ & 2.26 & 6.61 & 3.25 & 0.27 & 7.50 & 22 & 11 & 0.90 & $\leq \mathrm{LOD}$ & 7.00 & $\leq \mathrm{LOD}$ & 0.43 \\
\hline $\mathrm{S}_{2}$ & 1.62 & 3.96 & 2.55 & 0.30 & 5.40 & 13 & 8.5 & 1.00 & $\leq \mathrm{LOD}$ & $\leq \mathrm{LOD}$ & $\leq \mathrm{LOD}$ & 0.17 \\
\hline$S_{3}$ & 2.00 & 5.18 & 2.55 & 0.28 & 6.67 & 18 & 8.5 & 0.93 & $\leq \mathrm{LOD}$ & 5.1 & $\leq \mathrm{LOD}$ & $\leq \mathrm{LOD}$ \\
\hline $\mathrm{S}_{5}$ & 1.64 & 3.88 & 2.59 & 0.84 & 5.47 & 13 & 8.6 & 2.80 & $\leq \mathrm{LOD}$ & $\leq \mathrm{LOD}$ & $\leq \mathrm{LOD}$ & $\leq \mathrm{LOD}$ \\
\hline$S_{6}$ & 2.97 & 6.17 & 2.16 & 0.25 & 9.90 & 21 & 7.2 & 0.83 & $\leq \mathrm{LOD}$ & $\leq \mathrm{LOD}$ & $\leq \mathrm{LOD}$ & 0.19 \\
\hline $\mathrm{S}_{8}$ & 2.54 & 4.02 & 2.90 & 0.20 & 8.47 & 13 & 9.6 & 0.67 & $\leq \mathrm{LOD}$ & $\leq \mathrm{LOD}$ & $\leq \mathrm{LOD}$ & $\leq \mathrm{LOD}$ \\
\hline
\end{tabular}

$[C]^{*}$ - Metal concentrations found in the samples

Table 15. Metal concentrations found in the samples, LOD and LOQ found for the analytical curves of the samples and for the aqueous standard

As can be seen in Table 15, all the samples presented concentrations of $\mathrm{Cu}$ below the LOD. As for $\mathrm{Pb}$, only the concentrations found in samples $\mathrm{S}_{1}$ and $\mathrm{S}_{3}$ were above the LOD, but were below the LOQ. The concentrations of $\mathrm{Ni}$ found in the samples also fell below the limits of

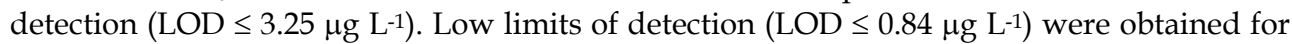
$\mathrm{Cd}$ by the analyte addition method, although they were higher than those obtained for the microemulsion. Cadmium was not quantified in sample $\mathrm{A}_{5}$ by this method.

Table 18 indicates that low limits of detection ( $\mathrm{LOD} \leq 0.85 \mu \mathrm{g} \mathrm{L}^{-1}$ ) were obtained for $\mathrm{Ni}$, but $\mathrm{Ni}$ in the samples was also undetectable by this method. The probable reasons for this are the same as those mentioned in item 3.4.1.

\subsubsection{Analyte addition and recovery test}

Table 16 shows the addition and recovery results for each sample.

\begin{tabular}{|c|c|c|c|c|}
\hline \multirow{2}{*}{ Sample } & \multicolumn{4}{|c|}{ Recovery rates, \% \pm RSD } \\
\cline { 2 - 5 } & $\mathbf{C u} \pm$ RSD $^{*}$ & Pb \pm RSD & Ni \pm RSD & Cd \pm RSD \\
\hline$S_{1}$ & $99 \pm 2.18$ & $111 \pm 3.30$ & $97 \pm 6.80$ & $103 \pm 0.90$ \\
\hline$S_{2}$ & $98 \pm 1.40$ & $101 \pm 4.70$ & $100 \pm 5.03$ & $100 \pm 0.29$ \\
\hline$S_{3}$ & $101 \pm 1.64$ & $124 \pm 8.50$ & $101 \pm 5.53$ & $105 \pm 1.68$ \\
\hline$S_{5}$ & $106 \pm 5.80$ & $114 \pm 4.90$ & $102 \pm 2.53$ & $101 \pm 2.41$ \\
\hline$S_{6}$ & $91 \pm 1.64$ & $106 \pm 1.38$ & $98 \pm 3.15$ & $100 \pm 1.92$ \\
\hline$S_{8}$ & $103 \pm 2.70$ & $100 \pm 5.30$ & $95 \pm 5.30$ & $95 \pm 1.39$ \\
\hline
\end{tabular}

*RSD - relative standard deviation

Table 16. Recovery rates $(n=3)$ and relative standard deviations (in parentheses) of biodiesel samples prepared with $10 \mu \mathrm{gL}^{-1}$ of $\mathrm{Cu}, 15 \mu \mathrm{g} \mathrm{L}^{-1} \mathrm{of} \mathrm{Pb}, 10 \mu \mathrm{g} \mathrm{L}^{-1}$ of $\mathrm{Ni}$ and $1.0 \mu \mathrm{g} \mathrm{L}^{-1}$ of Cd, using $W$ as modifier

Table 16 indicates that the recovery rates varied from $91 \%$ to $106 \%$ for $\mathrm{Cu}$, from $100 \%$ to $124 \%$ for $\mathrm{Pb}, 95 \%$ to $102 \%$ for $\mathrm{Ni}$, and $95 \%$ to $105 \%$ for $\mathrm{Cd}$. Hence, despite the low concentrations found in the samples (Table 15), the method employed here is suitable for the determination of these analytes in biodiesel matrices from different sources and origins. 
Satisfactory RSD values were obtained, i.e., $\leq 5.80 \%$ (sample $\mathrm{S}_{5}$ ) for $10 \mu \mathrm{g} \mathrm{L}^{-1}$ of $\mathrm{Cu} ; \leq 8.50 \%$ (sample $\mathrm{S}_{3}$ ) for $15 \mu \mathrm{g} \mathrm{L}^{-1}$ of $\mathrm{Pb} ; \leq 6.80 \%$ (sample $\mathrm{S}_{1}$ ) for $10 \mu \mathrm{g} \mathrm{L}^{-1}$ of $\mathrm{Ni}$, and $\leq 2.41 \%\left(\mathrm{~S}_{5}\right)$ for 1.0 $\mu \mathrm{g} \mathrm{L} \mathrm{L}^{-1}$ of $\mathrm{Cd}$.

\subsection{Comparison of the microemulsion and focused microwave digestion procedures}

Table 17 lists the values of $C d$ in samples $S_{1}, S_{2}, S_{3}, S_{5}, S_{6}$ and $S_{8}$ determined by the two methods, i.e., using samples in the microemulsified and digested forms.

\begin{tabular}{|c|c|c|c|c|c|c|}
\hline \multirow[t]{2}{*}{ Sample } & \multicolumn{2}{|c|}{$\begin{array}{c}\text { LOD found, } \\
\mu \mathrm{g} \mathrm{L}^{-1} \\
\end{array}$} & \multicolumn{2}{|c|}{$\begin{array}{c}\mathrm{LOQ}_{\text {found, }} \\
\mu \mathrm{g} \mathrm{L}^{-1}\end{array}$} & \multicolumn{2}{|c|}{$\begin{array}{c}{[\mathrm{C}]_{\text {obtained in the }}} \\
\text { sample, } \mu \mathrm{g} \mathrm{g}^{-1}\end{array}$} \\
\hline & $C d_{M E}^{*}$ & $C d_{D}^{* *}$ & $C d_{M E}^{*}$ & $C d_{D}^{* *}$ & $C d_{M E^{*}}$ & $C d_{D}{ }^{* *}$ \\
\hline$S_{1}$ & 0.10 & 0.27 & 0.36 & 0.90 & 0.66 & 0.43 \\
\hline $\mathrm{S}_{2}$ & 0.093 & 0.30 & 0.31 & 1.00 & 0.61 & 0.17 \\
\hline $\mathrm{S}_{3}$ & 0.07 & 0.28 & 0.34 & 0.93 & 0.33 & $\leq \mathrm{LOD}$ \\
\hline $\mathrm{S}_{5}$ & 0.12 & 0.84 & 0.40 & 2.80 & $\leq \mathrm{LOD}$ & $\leq \mathrm{LOD}$ \\
\hline $\mathrm{S}_{6}$ & 0.12 & 0.25 & 0.39 & 0.83 & 0.21 & 0.19 \\
\hline
\end{tabular}

$\mathrm{ME}^{*}$ - Microemulsified; $\mathrm{D}^{* *}$ - Digested

Table 17. Concentrations of Cd obtained in the samples, and LOD and LOQ of the samples using the different sample preparation procedures

As can be seen in Table 17, the analyte addition method resulted in low limits of detection (LOD $\leq 0.84 \mu \mathrm{g} \mathrm{L}^{-1}$ ) of $\mathrm{Cd}$ for the two methods of sample preparation, but the LODs obtained by the digestion method were higher. The concentrations found in the digested samples were consistently lower than those found in the microemulsified samples due to a possible loss of analyte during digestion. This is because the microwave used here has a semiopen configuration, and despite the reflux, the analyte may have undergone particle evaporation (Meeravali \& Kumar, 2001).

Sample $S_{5}$ (washed animal fat) did not show the same quantifiable concentration of $\mathrm{Cd}$ in the two procedures (Tables 13 and 15). Sample $S_{8}$ presented different results, because B10 is a sample of biodiesel mixed with diesel. The only samples that presented a consistent concentration of $\mathrm{Cd}$ by the two methods were $\mathrm{S}_{1}, \mathrm{~S}_{2}$ and $\mathrm{S}_{6}$.

The F-test is a hypothesis test used to ascertain if the variances of two given determinations are different, or to verify which of the two determinations shows greater variability. The Ftest was also applied to verify if the variances were the same or different, and the $\mathrm{F}_{\text {calculated }}$ values were found to be consistently lower than the $\mathrm{F}_{\text {tabulated }}$ value at a $95 \%$ level of confidence. Thus, it can be concluded that there are no significant differences between the two accuracies at the $95 \%$ level of confidence.

The $t$-test is a statistical tool widely employed to verify the concurrency between averages. Student's $t$-test was performed to evaluate the samples by comparing individual differences, since each sample was measured by the microemulsion and digestion methods, which do not yield exactly the same results. The $t_{\text {calculated }}$ value was lower than the $t_{\text {tabulated }}$ value at a $95 \%$ level of confidence. Hence, the two methods are not significantly different at the $95 \%$ level of confidence.

Table 18 summarizes the analytical characteristics of the analytes in the two methods developed. 


\begin{tabular}{|c|c|c|c|c|c|c|c|c|}
\hline \multirow{2}{*}{ PARAMETERS } & \multicolumn{4}{|c|}{ MICROEMULSION } & \multicolumn{4}{|c|}{ MICROWAVE DIGESTION } \\
\hline & $\mathrm{Cu}$ & $\mathbf{P b}$ & $\mathbf{N i}$ & $\mathrm{Cd}$ & $\mathrm{Cu}$ & $\mathbf{P b}$ & $\mathbf{N i}$ & Cd \\
\hline Pyrolysis temperature, ${ }^{\circ} \mathrm{C}$ & 8 & 500 & 800 & 500 & 1000 & 500 & 800 & 500 \\
\hline $\begin{array}{l}\text { Atomization temperature, } \\
{ }^{\circ} \mathrm{C}\end{array}$ & 2200 & 2000 & 2300 & 1400 & 2200 & 2000 & 2300 & 1400 \\
\hline Volume of sample, $\mu \mathrm{L}$ & \multicolumn{8}{|c|}{20} \\
\hline $\begin{array}{c}\text { Linear calibration interval } \\
\text { used, } \mu \mathrm{g} \mathrm{L}^{-1}\end{array}$ & $5-15$ & $15-45$ & $5-15$ & $0.5-1.5$ & $5-15$ & $15-45$ & $5-15$ & $0.5-1.5$ \\
\hline Characteristic mass, pg & $\mathrm{nd}^{*}$ & $\mathrm{nd}^{*}$ & $\leq 11$ & $\leq 2$ & $\leq 41$ & $\leq 54$ & $\leq 25$ & $\leq 2$ \\
\hline Recovery rates, $\%$ & $\mathrm{nd}^{*}$ & $\mathrm{nd}^{*}$ & $93-108$ & $95-116$ & $91-106$ & $100-124$ & $95-102$ & $95-105$ \\
\hline Modifier mass $(\mu \mathrm{g})$ & \multicolumn{8}{|c|}{200} \\
\hline $\begin{array}{l}\text { Graphite tube service life } \\
\text { (avg. of the no. of firings) }\end{array}$ & \multicolumn{4}{|c|}{520} & \multicolumn{4}{|c|}{450} \\
\hline $\begin{array}{c}\text { Analytical rate } \\
\text { (determinations per hour) }\end{array}$ & \multicolumn{8}{|c|}{40} \\
\hline $\begin{array}{c}\text { Relative standard } \\
\text { deviation } \\
\text { RSD, } n=12), m L\end{array}$ & $\mathrm{nd}^{*}$ & $\mathrm{nd}^{*}$ & $\leq 8.20 \%$ & $\leq 4.71 \%$ & $\leq 5.80 \%$ & $\leq 8.50 \%$ & $\leq 6.80$ & $\leq 2.41$ \\
\hline LOD, $\mu \mathrm{g} \mathrm{L}^{-1}$ & $\mathrm{nd}^{*}$ & $\mathrm{nd}^{*}$ & $\leq 1$ & $\leq 0.12$ & $\leq 3$ & $\leq 7$ & $\leq 4$ & $\leq 0.84$ \\
\hline $\mathrm{LOQ}, \mu \mathrm{g} \mathrm{L}^{-1}$ & $\mathrm{nd}^{*}$ & $\mathrm{nd}^{*}$ & $\leq 3$ & $\leq 3$ & $\leq 10$ & $\leq 22$ & $\leq 11$ & $\leq 3$ \\
\hline
\end{tabular}

nd $^{*}$ - not determined

Table 18. Analytical characteristics of the proposed methods for the determination of $\mathrm{Cu}, \mathrm{Pb}$, $\mathrm{Ni}$ and $\mathrm{Cd}$ in biodiesel using $\mathrm{W}$ as modifier and two sample preparation procedures

\section{Conclusions}

Multivariate optimization techniques are currently applied preferentially in analytical chemistry because, among other advantages, they allow for the simultaneous optimization of all the factors involved in the system with fewer experiments, greater speed, and particularly higher efficiency. Despite these multiple advantages, however, multivariate techniques have only been effectively and increasingly employed in the optimization of analytical methods in the last few decades. Factorial design was employed in this work, confirming its importance in evaluating the significance of several variables, as well as in indicating optimal conditions to obtain the best results. Another aspect to be highlighted is the fewer experiments required with factorial design when compared to the traditional method (univariate). A maximum of 16 experiments were performed to optimize the pyrolysis and atomization temperatures for each element, instead of the 17 to 25 experiments the literature reports for the traditional method.

The pyrolysis and atomization temperatures for the determination of $\mathrm{Cu}, \mathrm{Cd}, \mathrm{Ni}$ and $\mathrm{Pb}$ were determined based on the graphics of value of the effects. Using these graphics, it was found that for the analytes $\mathrm{Cu}$ and $\mathrm{Pb}$, preparation of the sample in digested form was the only significant variable; hence, these elements were analyzed only in focused microwavedigested samples. None of the evaluated variables were important for Ni. The optimal 
pyrolysis (Tp) and atomization (Ta) temperatures found were, respectively: $\mathrm{Cu} 1000^{\circ} \mathrm{C}$ and $2200{ }^{\circ} \mathrm{C}, \mathrm{Pb} 500{ }^{\circ} \mathrm{C}$ and $2000{ }^{\circ} \mathrm{C}$, and $\mathrm{Ni} 800^{\circ} \mathrm{C}$ and $2300^{\circ} \mathrm{C}$. For $\mathrm{Cd}$, the pyrolysis temperature had to be increased and the atomization temperature decreased to ensure the highest efficiency of the process. A $2^{2}$ factorial design was created with four experiments. This factorial design has two levels corresponding to the lowest (-1) and highest (+1) temperatures for two variables (temperatures of pyrolysis and of atomization). The results indicate that the values of the effects were very slight for the design used here, since the lowest temperatures were chosen, i.e., $\mathrm{Tp}-500^{\circ} \mathrm{C}$ and $\mathrm{Ta}-1400^{\circ} \mathrm{C}$. The other variables were unimportant. It was decided to work with $\mathrm{W}$ because the analyses are faster, there is less contamination, few problems involving background and incompatibility among solutions, and because $\mathrm{W}$ is a permanent modifier, which may increase the service life of the atomizer. The analytical procedures developed here using microemulsion can be considered satisfactory, for they exhibited good recovery rates and low RSD values.

The main advantage of the procedures employed here is that they enable the use of inorganic standards for the determinations, instead of organic solvents, which have some drawbacks such as the need for suitable equipment, connections and apparatuses in view of to their toxicity and their chemical instability.

Although some of the elements were not determined in the samples analyzed by these methods, the LOD and LOQ were low. Therefore, they are interesting since, if the respective analytes are present in the biodiesel samples analyzed here, their concentrations are lower than $3 \mu \mathrm{g} \mathrm{L}^{-1}$ (which is the highest LOQ found). These values are much lower than those reported in the literature for these elements in fossil fuels. From the environmental standpoint, this can be considered a positive aspect of biodiesel, since some elements, for example $\mathrm{Ni}$, are natural constituents of petroleum and are usually found in high concentrations in its derivatives.

This work contributes towards the establishment or proposal of a suitable standard, which is still absent from the literature and/or current legislation, in terms of the quality control of these metals in biodiesel samples. Moreover, it enables the prediction of possible environmental impacts resulting from the production, transportation and use of fuels such as biodiesel.

\section{Acknowledgments}

The authors thank the Brazilian research funding agencies FAPESP, CNPq and FUNDUNESP for their financial support and grants. The authors are also indebted to UFMT - Universidade Federal de Mato Grosso for providing the biodiesel samples used in this work and to Professor Edenir Pereira Filho for his assistance in the initial part of the experiments. We also thank the anonymous reviewers for their comments, which were helpful in improving the manuscript.

\section{References}

Agarwal, A.K. (2005). Experimental investigations of the effect of biodiesel utilization on lubricating oil tribology in diesel engines. Proc. Inst. Mech. Eng. Transp. Eng., Vol. 219, pp. (703-713).

AGÊNCIA NACIONAL DO PETRÓLEO, GÁS NATURAL E BIOCOMBUSTÍVEIS. Portaria $\mathrm{n}^{\circ} 311$, de 27 de dezembro de 2001. Estabelece os procedimentos de controle de qualidade na importação de petróleo, seus derivados, álcool etílico combustível, 
biodiesel e misturas óleo diesel/biodiesel. Diário Oficial da União, Brasília, DF, 28 de dezembro de 2001. Available at:

http://nxt.anp.gov.br/NXT/gateway.dll/leg/folder_portarias_anp/portarias_anp _tec/2001/dezembro/panp $\% 20311 \% 20$ -

$\%$ 202001.xml?f=templates $\$ \mathrm{fn}=$ default.htm\&sync=1\&vid=anp:10.1048/enu.

Consulted on: 10 May 2009.

Amorim, F.R.; Bof, C.; Franco, M.B.; Silva J.B.; Nascentes, C.C. (2006). Comparative study of conventional and multivariate methods for aluminum determination in soft drinks by graphite furnace atomic absorption spectrometry. Microchem. J., Vol. 82, pp. (168-173).

Arzamendi, G.; Arguinãrena, E.; Campo, I.; Zabala, S.; Gandiá, L.M. (2008). Alkaline and alkaline-earth metals compounds as catalysts for the methanolysis of sunflower oil Catal. Today, Vol. 133-135, pp. (305-313).

Aucélio, R.Q.; Doyle, A.; Pizzorno, B.S.; Tristão, M.L.B.; Campos, R.C. (2004). Electrothermal atomic absorption spectrometric method for the determination of vanadium in diesel and asphaltene prepared as detergentless microemulsions. Microchem. J., Vol. 78, pp. (21-26).

Baccan, N.; Andrade, J.C.; Godinho, O.E.S.; Barone, J.S. (1985) Química analítica quantitativa elementar. 2. ed. Campinas: Ed. UNICAMP, Campinas.

Bettinelli, M.; Spezia, S.; Baroni, U.; Bizzarri, G. (1996).The use of reference materials in fossil fuel quality control. Microchim. Acta, Vol. 123, pp. (217-230).

Campos, M.L.; Silva, F.N.; Furtini Neto, A E.F.; Guilherme, L.R.G.; Marques, J.J.; Antunes, A.S. (2005). Determinação de cádmio, cobre, cromo, níquel, chumbo e zinco em fosfatos de rocha. Pesq. Agropec. Bras., Vol. 40, pp. (361-367).

Canakci, M.; Monyem, A.; Van Gerpen, J. (1999). Accelerated oxidation processes in biodiesel. Trans. of the Asae, Vol. 42, pp. (1565-1572).

Cassella, R.J.; Barbosa, B.A.R.S.; Santelli, R.E.; Rangel, A.T. (2004). Direct determination of arsenic and antimony in naphtha by electrothermal atomic absorption spectrometry with microemulsion sample introduction and iridium permanent modifier. Anal. Bioanal. Chem., Vol. 379, pp. (66-71).

Chaves, E.S.; dos Santos, E.J.; Araujo, R.G.O.; Oliveira, J.V.; Frescura, V.L.A.; Curtius, A.J. (2010). Metals and phosphorus determination in vegetable seeds used in the production of biodiesel by ICP OES and ICP-MS. Microchem. J., Vol. 96, No. 1, pp. (71-76).

Chaves, E.S.; Saint'Pierre, T.D.; Santos, E.J.; Tormen, L.V.; Bascunana, L.A.F.; Curtius, A. (2008a). Determination of $\mathrm{Na}$ and $\mathrm{K}$ in biodiesel by flame atomic emission spectrometry and microemulsion sample preparation. J. Braz. Chem. Soc., Vol. 19, No. 5, pp. (856-861).

Chaves, E.S.; Saint'Pierre, T.D.; Santos, E.J.; Tormen, L.V.; Bascunana, L.A.F.; Curtius, A. (2008b). Determination of $\mathrm{Na}$ and $\mathrm{K}$ in biodiesel by flame atomic emission spectrometry and microemulsion sample preparation. J. Braz. Chem. Soc., Vol. 19, No. 5, pp. (856-861).

Coronado, C.R.; Villela, A.D.; Silveira, J.L. (2010). Ecological efficiency in CHP: Biodiesel case. Applied Thermal Engineering. Vol. 30, No. 5, pp. (458-463).

Costa Neto, P.R.; Rossi, L.F.S.; Zagonel, G.F.; Ramos, L.P. (2000). Produção de biocombustível alternativo ao óleo diesel através da transesterificação de óleo de soja usado em frituras. Quim. Nova, Vol. 23, No. 4, pp. (531-537).

Ferrari, R.A.; Oliveira, V.S.; Scabio, A. (2005). Biodiesel de soja - taxa de conversão em ésteres etílicos, caracterização físico-química e consumo em gerador de energia, Quim. Nova, Vol. 28, No. 1, pp. (19-23). 
Figueiredo, J.L.; Ribeiro, F.R. (1987). Desativação de catalisadores. Catálise heterogênea. Lisboa: Fundação Calouste Gulbekian, pp. (219-252), Lisboa.

Freschi, C.S.D.; Freschi, G.P.G.; Gomes Neto, J.A.; Nobrega, J.A.; Oliveira, P.V. (2005). Arsenic as internal standard to correct for interferences in determination of antimony by hydride generation in situ trapping graphite furnace atomic absorption spectrometry. Spectrochim. Acta Part B, Vol. 60, No. 5, pp. (759-763).

Giacomelli, M.B.O.; Silva, J.B.B.; Saint'Pierre, T.D.; Curtius, A.J. (2004). Use of iridium plus rhodium as permanent modifier to determine $\mathrm{As}, \mathrm{Cd}$ and $\mathrm{Pb}$ in acids and ethanol by electrothermal atomic absorption spectrometry. Microchem. J., Vol. 77, pp. (151-156).

Harris, D.C. (2001). Análise química quantitativa. 5. ed. Rio de Janeiro.

Haseeb, A.S.M.A.; Masjuki, H.H.; Ann, L.J.; Fazal, M.A. (2010). Corrosion characteristics of copper and leaded bronze in palm biodiesel. Fuel Processing Technology. Vol. 91, No. 3, pp. (329-334).

Hernández-Caraballo, E.A.; Burguera, M.; Burguera, J.L. (2004). Determination of cadmium in urine specimens by graphite furnace atomic absorption spectrometry using a fast atomization program. Talanta, Vol. 63, pp. (419-424).

Ilkilic, C.; Behcet, R. (2010). Energy sources - Part A - Recovery utilization and environmental effects. The Reduction of Exhaust Emissions from a Diesel Engine by Using Biodiesel Blend. Vol. 32, No. 9, pp. (839-850).

Jackson, K. W. (1999). Electrothermal atomization for analytical atomic spectrometry. Chichester: John Wiley, England.

Jesus, A.; Silva, M.M.; Vale, M.G.R. (2008). The use of microemulsion for determination of sodium and potassium in biodiesel by flame atomic absorption spectrometry. Talanta, Vol. 74, pp. (1378-1384).

Jesus, A.; Zmozinski, A.V.; Barbara, J.A.; Vale, M.G.R.; Silva, M.M. (2010). Determination of Calcium and Magnesium in Biodiesel by Flame Atomic Absorption Spectrometry Using Microemulsions as Sample Preparation. Energy Fuels, Vol. 24, pp. (2109-2112).

Liu, J.; Sturgeon, R.E.; Willie, S.N. (1995). Open-focused microwave-assisted digestion for the preparation of large mass organic samples. Analyst. Vol. 120, pp. (1905-1909).

Lobo, F.A.; Gouveia, D.; Oliveira A.P.; Romão, L.P.C.; Fraceto, L.F.; Dias, N.L.; Rosa, A.H. (2011). Development of a method to determine $\mathrm{Ni}$ and $\mathrm{Cd}$ in biodiesel by graphite furnace atomic absorption spectrometry. Fuel, Vol. 90, No. 1, pp. (142-146).

López, D.E.; Goodwin Jr., J.G.; Bruce, D.A.; Lotero, E. (2005). Transesterification of triacetin with methanol on solid acid and base catalysts. Appl. Catal., Vol. 295, pp. (97-105).

Ma, F.; Hanna, M.A. (1999). Biodiesel production: a review. Bioresour. Technol., Vol. 70, pp. (1-15).

Meeravali, N.N.; Kumar, S.J. (2001). The utility of a W-Ir permanent chemical modifier for the determination of $\mathrm{Ni}$ and $\mathrm{V}$ in emulsified fuel oils and naphtha by transverse heated electrothermal atomic absorption spectrometry. J. Anal. Atom. Spectrom., Vol.. 16, No. 5, pp. (527-532).

Meher, L.C.; Dharmagadda, V.S.S.; Naik, S.N. (2006). Optimization of alkali-catalyzed transesterification of Pongamia pinnata oil for production of biodiesel. Bioresour. Technol., Vol. 97, pp. (1392-1397).

Nigam, P.S.; Singh, A. (2011). Production of liquid biofuels from renewable resources. Progress in Energy and Combustion Science, Vol. 37, No. 1, pp. (52-68).

Oliveira, A.P.; Gomes Neto, J.A.; Moraes, M.; Lima, E.C. (2002). Direct determination of Al, $\mathrm{As}, \mathrm{Cu}, \mathrm{Fe}, \mathrm{Mn}$ and $\mathrm{Ni}$ in fuel ethanol by simultaneous GFAAS using integrated platforms pretreated with W-Rh permanent modifier together with $\mathrm{Pd}+\mathrm{Mg}$ modifier. Atomic Spectroscopy, Vol. 23, No. 6, pp. (190-195). 
Oliveira, A.P.; Villa, R.D.; Antunes, K.C.P.; Magalhães, A.; Silva, E.C. (2009). Determination of sodium in biodiesel by flame atomic emission spectrometry using dry decomposition for the sample preparation. Fuel, Vol. 88, pp. (764-766).

Oliveira, J.A.; Cambraia, J.; Cano, M.A.O.; Jordão, C.P. (2001). Absorção e acúmulo de cádmio e seus efeitos sobre o crescimento relativo de plantas de aguapé e de salvínia. R. Bras. Fisiol. Veg., Vol. 13, pp. (329-341).

Pereira Filho, E.R.; Poppi, R.J.; Arruda, M.A.Z. (2002). Emprego de planejamento fatorial para a otimização das temperaturas de pirólise e atomização de $\mathrm{Al}, \mathrm{Cd}, \mathrm{Mo} \mathrm{e} \mathrm{Pb}$ por ETAAS. Quim. Nova, v. 25, n. 2, p. (246-253).

Pohl, P.; Vorapalawut, N.; Bouyssiere, B.; Carrier, H.; Lobinski, R. (2010). Direct multielement analysis of crude oils and gas condensates by double-focusing sector field inductively coupled plasma mass spectrometry (ICP MS). Journal of Analytical Atomic Spectrometry. Vol. 25, No. 5, pp. (704-709).

Ramadhas, A.S.; Jayaraj, S.; Muraleedharan, C. (2004). Use of vegetable oils as I.C. engine fuels: a review. Renewable Energy, Vol. 29, pp. (727-742).

Reyes, M.N.M.; Campos, R.C. (2005). Graphite furnace absorption spectrometric determination of $\mathrm{Ni}$ and $\mathrm{Pb}$ in diesel and gasoline samples stabilized as microemulsion using conventional and permanent modifiers. Spectrochim. Acta Part $B$, Vol. 60, pp. (615-624).

Sahin, Y. (2011). Energy education science and technology, Part A - Energy science and research. Environ. impacts of biofuels, Vol. 26, No. 2, pp. (129-142).

Saint'Pierre, T.D.; Dias, L.F.; Maia, S.M.; Curtius, A.J. (2004). Determination of Cd, Cu, Fe, $\mathrm{Pb}$ and $\mathrm{Tl}$ in gasoline as emulsion by electrothermal vaporization inductively coupled plasma mass spectrometry with analyte addition and isotope dilution calibration techniques. Spectrochim. Acta Part B, Vol. 59, pp. (551-558).

Saint’Pierre, T.D.; Dias, L.F.; Pozebon, D.; Aucélio R.Q.; Curtius A.J.; Welz, B. (2002). Determination of $\mathrm{Cu}, \mathrm{Mn}, \mathrm{Ni}$ and $\mathrm{Sn}$ in gasoline by electrothermal vaporization inductively coupled plasma mass spectrometry, and emulsion sample introduction. Spectrochim. Acta Part B, Vol. 57, No. 12, pp. (1991-2001).

Saint'Pierre, T.D.; Frescura, V.L.A.; Aucélio, R.Q. (2006).The development of a method for the determination of trace elements in fuel alcohol by ETV-ICP-MS using isotope dilution calibration. Talanta, Vol. 68, pp. (957-962).

Saint'Pierre, T.D.; Aucélio, R.Q.; Curtius A.J. (2003). Trace elemental determination in alcohol automotive fuel by electrothermal atomic absorption spectrometry. Microchem. J., Vol. 75, No. 1, pp. (59-67).

Silva, J.S.A.; Chaves, E.S.; Santos, E.J.; Saint’Pierre, T.D.; Frescura, V.L.; Curtius, A.J. (2010). Calibration Techniques and Modifiers for the Determination of $\mathrm{Cd}, \mathrm{Pb}$ and $\mathrm{Tl}$ in Biodiesel as Microemulsion by Graphite Furnace Atomic Absorption Spectrometry. J Braz Chem Soc, Vol. 21, pp. (620-626).

Vale, M.G.R.; Damin, I.C.F.; Klassen, A.; Silva, M.M.; Welz, B.; Silva, A.F.; Lepri, F.G. (2004). Method development for the determination of nickel in petroleum using linesource and high-resolution continuum-source graphite furnace atomic absorption spectrometry. Microchem. J., Vol. 77, pp. (131-140).

Vogel, A. (1992). Química analítica quantitativa. (5. ed.), LCD, Rio de Janeiro.

Welz, B.; Schlemmer, G.; Mudakavi, J.R. (1992). Palladium nitrate-magnesium nitrate modifier for electrothermal atomic absorption spectrometry. Part 5. Performance for the determination of 21 elements. J. Anal. At. Spectrom., v. 7, p. (1257-1271).

Woods, G.D.; Fryer, F.I. (2007). Direct elemental analysis of biodiesel by inductively coupled plasma-mass spectrometry. Anal. Bioanal. Chem., Vol. 389, pp. (753-761). 


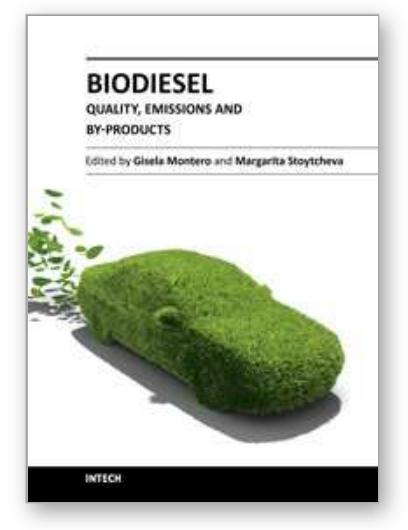

\author{
Biodiesel- Quality, Emissions and By-Products \\ Edited by Dr. Gisela Montero
}

ISBN 978-953-307-784-0

Hard cover, 380 pages

Publisher InTech

Published online 16, November, 2011

Published in print edition November, 2011

This book entitled "Biodiesel: Quality, Emissions and By-products" covers topics related to biodiesel quality, performance of combustion engines that use biodiesel and the emissions they generate. New routes to determinate biodiesel properties are proposed and the process how the raw material source, impurities and production practices can affect the quality of the biodiesel is analyzed. In relation to the utilization of biofuel, the performance of combustion engines fuelled by biodiesel and biodiesels blends are evaluated. The applications of glycerol, a byproduct of the biodiesel production process as a feedstock for biotechnological processes, and a key compound of the biorefinery of the future is also emphasized.

\title{
How to reference
}

In order to correctly reference this scholarly work, feel free to copy and paste the following:

Fabiana A. Lobo, Danielle Goveia, Leonardo F. Fraceto and André H. Rosa (2011). Analytical Methodology for the Determination of Trace Metals in Biodiesel, Biodiesel- Quality, Emissions and By-Products, Dr. Gisela Montero (Ed.), ISBN: 978-953-307-784-0, InTech, Available from: http://www.intechopen.com/books/biodieselquality-emissions-and-by-products/analytical-methodology-for-the-determination-of-trace-metals-in-biodiesel

\section{INTECH}

open science | open minds

\section{InTech Europe}

University Campus STeP Ri Slavka Krautzeka 83/A 51000 Rijeka, Croatia Phone: +385 (51) 770447

Fax: +385 (51) 686166 www.intechopen.com

\section{InTech China}

Unit 405, Office Block, Hotel Equatorial Shanghai No.65, Yan An Road (West), Shanghai, 200040, China 中国上海市延安西路65号上海国际贵都大饭店办公楼 405 单元 Phone: +86-21-62489820

Fax: $+86-21-62489821$ 
(C) 2011 The Author(s). Licensee IntechOpen. This is an open access article distributed under the terms of the Creative Commons Attribution 3.0 License, which permits unrestricted use, distribution, and reproduction in any medium, provided the original work is properly cited. 